\title{
Åshild Næss* \\ Standing up to the canoe: Competing cognitive biases in the encoding of stative spatial relations in a language with a single spatial preposition
}

https://doi.org/10.1515/cog-2017-0096

Received August 08, 2017; revised April 05, 2018; accepted April 08, 2018

\begin{abstract}
This paper discusses how verbal directional markers are used to encode stative spatial relations in the Oceanic language Äiwoo. It argues that the apparent reversal of directional meaning in stative expressions, where 'up' is used in expressions meaning 'underneath', 'down' in expressions meaning 'above', and 'out' in expressions meaning 'inside', can be explained by a fictive motion analysis where the figure is construed as metaphorically moving towards the ground. It moreover argues that in expressions where motion leads to a resulting spatial configuration, where 'up' means 'on top of' rather than 'underneath', this reading is overridden by the so-called goal bias, whereby the resultant configuration is more cognitively salient than the motion producing it. It suggests that the linguistic construal of stative spatial relations may to some extent be correlated with the formal means of expression, where marking by adpositions favours a 'search domain' construal whereas encoding within the verb favours a 'fictive path' construal. It thus provides a new angle on the linguistic encoding of spatial relations, an area which has been subject to much research within cognitive linguistics, but which so far has paid little attention to the possibility of encoding stative spatial relations within the verb.
\end{abstract}

Keywords: spatial language, Oceanic, goal bias, fictive motion, directional

\section{Introduction}

This paper describes how stative spatial relations such as 'above', 'below', 'inside' and 'next to' are encoded in the Oceanic language Äiwoo. Äiwoo has only a single spatial preposition; other means are therefore necessary to distinguish between different spatial relations such as 'on', 'in', 'above', 'below', etc. While the language has several such means, the paper focuses on the most

*Corresponding author: Åshild Næss, Department of Linguistics and Scandinavian Studies, University of Oslo, Oslo, Norway, E-mail: ashild.nass@iln.uio.no 
unusual, namely the use of so-called directional morphemes within the verb complex. There are two sets of such directionals, a topological set ('up', 'down', 'in', 'out') and a deictic set ('towards 1st/2nd/3rd person'); in their canonical use they indicate the direction in which a verbal action is carried out. In expressions of stative relations, however, a directional from the topological set can combine with one from the deictic set to yield expressions translating as 'below, underneath', 'above, on top of', 'inside', and 'next to'. Strikingly, in such constructions, the contribution of the topological directional is in most cases the opposite of what one might expect, in that the 'up' directional is found in the form meaning 'underneath', the 'down' directional in the form meaning 'above', and the 'out' directional in the form meaning 'inside'. To add to the complexity, in descriptions of motion events which result in a stative configuration (as in 'The water dripped onto the table', where the water ends up being on the table as a result of motion), ee 'up' is used to mean 'on top of', rather than 'underneath' as it does in constructions where only a stative relation is described.

I argue that this unusual pattern is the result of two competing cognitive biases, each well-documented in the literature, namely the bias towards dynamism (Talmy 2000) and the goal bias (Freeman et al. 1980; Lakusta and Landau 2005; Regier and Zheng 2007). The construction combining two directionals can be understood as an instance of fictive motion where the located object is construed as moving towards the Ground object, so that, for example, being underneath something is described as moving up towards it; a dynamic description of a stationary relation. By contrast, the construction that describes a configuration resulting from a motion event draws on a tendency for resulting configurations to be more salient than the motion that produces them (Regier and Zheng 2007). In combination with the specific semantics of the individual directionals and of the verbs involved in the different constructions, these biases explain how the directionals come to have such unexpected, and sometimes apparently contradictory, uses in descriptions of stative spatial relations.

While there is a vast literature on the language of space, the use of verbal morphemes to encode stative spatial relations has been little studied. The Äiwoo data provides an example of this, and as such provides a new angle on an area that has attracted a great deal of interest in cognitive linguistics for several decades. I suggest that the use of verbal directional morphemes to indicate stative spatial relations via a fictive path construction constitutes an alternative means for the linguistic organisation of such relations to the commonly cited concept of search domains (Hawkins 1981; Langacker 1987; Levinson 2003), whereby expressions such as '(in) front of $X$ ', 'next to $X$ ' serve to project a domain outwards from the relevant section of the object $X$ within which the located object is to be found. The stative spatial construction in Äiwoo seems to 
be better described in terms of tracing a mental path from the Figure to the Ground in order to establish the relative location of the two (Section 4)

The paper is structured as follows: Section 2 gives a general introduction to the Äiwoo language, and sketches the various means by which the language encodes spatial relations, with a focus on the semantics of the preposition ngä (2.3) and the system of directionals (2.5). Section 3 constitutes the main body of the paper and describes how directionals are used to indicate stative spatial relations. There are two main constructions, one where no motion is involved and a simple stative relation is described, and one where the stative relation comes about as a result of motion. I describe first the former construction, starting with verbs of position and location (3.1) where the patterns described are explained in terms of fictive motion (3.2). This analysis is compared to the description of a similar construction in the related language Caac in Cauchard (2014, ms), and I suggest that the Caac data provides a starting-point for understanding how the Äiwoo construction has grammaticalised (3.3). The role of the deictic directional in the Äiwoo construction is discussed in more detail in 3.4. I then look at how the same construction can be used with verbs other than those of position and location to locate the event as a whole relative to the speech situation (3.5). Next, I turn to the construction involving motion plus a resulting configuration, and illustrate its properties with inchoative posture verbs (3.6), verbs of vertical motion (3.7) and verbs of placement (3.8), before offering an analysis in terms of the goal bias and certain pragmatic inferences associated with 'up' (3.9) which I argue explains why this construction deviates from the first type in some crucial respects. Finally, Section 4 discusses the findings in a broader typological context, specifically with reference to the encoding of stative spatial relations in NPs/PPs vs. by means of verbal expressions, and offers some directions for future research in the domain of verbal encoding of stative spatial relations.

\section{The Äiwoo language}

\subsection{General properties}

Äiwoo is spoken by approximately 8,000 people in Temotu Province, the easternmost province of the Solomon Islands in the southwest Pacific. It is classified as belonging to the Oceanic subgroup of the Austronesian language family (Ross and Næss 2007). 
Traditionally, Äiwoo speakers appear to have been bilingual in the neighbouring Polynesian language Vaeakau-Taumako (Næss and Jenny 2011). At present, the main lingua franca is Solomon Islands Pijin, which is spoken by most of the population, while competence in Vaeakau-Taumako is claimed mostly by people living in the villages closest to the Vaeakau-Taumako communities. English is taught in school, but few people speak it with any confidence; while no systematic data on education levels is available, it is far from unusual for people to have attended only a few years of primary school.

Äiwoo tends towards long and complex verbal forms which can combine several verb roots or a verb plus one or more manner modifiers in a single form, as well as grammatical markers such as person marking and aspect/mood morphology. (The term "verb complex" is commonly used in Oceanic linguistics to describe such constellations of one or more verb roots and various dependent morphemes, and this convention is followed here.) The morphosyntax of nouns and noun phrases, by comparison, is relatively simple, with no articles, casemarking, or inflectional plural marking, and a tendency for modifiers to appear in the verb complex rather than in the NP where possible.

For the present paper, the key point is that spatial information is to a great extent encoded within the verb complex rather than in the noun phrase. There are adnominal demonstratives enge 'proximal' and eângâ 'distal', but only a single, schematic spatial preposition (2.3), which itself is much more frequent as a modifier within the verb phrase than in the noun phrase; meanings like 'the book on the table' are systematically rendered as 'the book that is lying on the table' rather than as a noun modified directly by a PP. By contrast, there is a rich array of forms with spatial meaning appearing within the verb complex. The focus of this paper is how the latter are used in order to describe stative relations between entities, such as 'the fish is in the net' or 'the picture is above the bed', that would more commonly be expressed by adpositions in languages which differentiate between different spatial adpositions such as in, on, above, below etc.

\subsection{Data}

This paper builds on data collected through fieldwork with native Äiwoo speakers in Honiara and the Reef Islands in 2004, 2005 and 2015. The 2004-2005 data includes audio recordings of a number of traditional narratives, as well as descriptions of photographs and video clips elicited by means of the tools Picture Series for Positional Verbs (Ameka et al. 1999), Staged Events (van Staden et al. 2001), Caused Positions (Hellwig and Lüpke 2001), Kids' Cut and 
Break (Bowerman and Majid 2003), and Put Project (Bowerman et al. 2004). Some spatial descriptions were also elicited by means of a self-designed task involving a number of balls and other objects placed on a table. The 2015 data consists of video and audio recorded monologues and dialogues on various aspects of traditional cultural practice, as well as sentences elicited mainly as illustrative examples for a dictionary (Næss 2017). The 2015 data is archived with ELAR (Endangered Languages Archive at SOAS University of London). ${ }^{1}$

\subsection{The spatial preposition}

$n g \ddot{a}^{2}$ is a general spatial preposition with a range of possible English translations such as 'in, on, at, to, from'. In other words, it indicates that a spatial relation exists between two entities, which I will refer to as the Figure and the Ground, but does not specify the nature of this relation. In many cases the semantics of the verb or other aspects of the sentence context will disambiguate, as in (1a-b):

a. Ikuwä ngâ nuwopa.

i-ku-wä ngâ nuwopa

1MIN-IPFV-go LOC house

'I'm going to the house.'

b. Ikitokoli ngâ nuwopa.

i-ki-tokoli ngâ nuwopa

1MIN-IPFV-sit LOC house

'I'm sitting in the house.'

In (1a), with the verb wä 'go', the ngä PP is interpreted as referring to the goal of motion, whereas in (1b), with the verb tokoli 'sit', it is interpreted as a location.

With verbs of motion, ngä can indicate either the source or the goal of motion; again, the semantics of the verb and/or directional modifiers may help to disambiguate, but this is not necessarily the case. Examples (2-3) show that the same verbs and directionals can be used with both a source and a goal

1 https://elar.soas.ac.uk/Collection/MPI1032004 (last accessed August 25, 2018).

2 In the orthography used for Äiwoo, $\ddot{a}$ represents an open front vowel [æ] while $\hat{a}$ represents a low back rounded or unrounded vowel $[a, b]$. In many (though not all) cases, $\ddot{a}$ undergoes assimilation and becomes $\hat{a}$ when the following syllable has a back vowel; thus ngä has the form $n g \hat{a}$ in examples such as (1). 
meaning of $n g \ddot{a}$, indicating that context and inference play an essential part in the interpretation of $n g \ddot{a}$ :

(2) a. Penyipe milupopweemä ngâ numobâ.

pe-nyipe mi-lu-popwee-mä ngâ numobâ

people-scale BN-3AUG-come.up-DIR:1 LOC hole

'The penyipe clan are the ones that came up from a hole.'

b. Lupopweemä ngä nyepolââ.

lu-popwee-mä ngä nye-polââ

3AUG-come.up-DIR:1 LOC place-clear

'They came up into the world.'

(3) Delâ eângâ lâ kiso ngä nyibä nâ lâ kiso ngâ daa täpilo kâ.

Delâ eângâ lâ ki-so ngä nyibä=nâ

blood DEM:DIST DIST IPFV-stand LOC eye.3MIN=DIST

lâ ki-so ngâ daa täpilo=kâ.

DIST IPFV-stand LOC bottom bowl=DIST

'The blood flowed from his eye and into the bowl.'

In (2a), the PP ngâ numobâ refers to the source of the motion ('came up from the hole'), while in (2b) the PP ngä nyepolâa refers to the goal of the motion ('came up into the world'). As both the verb and the directional -mä 'towards here, towards 1st person' are the same in both cases, the meaning difference clearly hinges on extralinguistic knowledge; the speech-situation presumably influences the interpretation here, in that the speech-act participants are located in the world, but not in the hole.

Example (3) shows another instance of the same verb being used with a source and a goal reading of $n g a ̈$, respectively. As is common when a language lacks distinct spatial adpositions for source and goal (cf. the "Type III" languages of Bohnemeyer etal. [2007], most of which lack an adpositionally marked source/goal distinction), it is impossible in Äiwoo to encode source and goal of the same motion event in a single clause. In (3), the motion is encoded by two sequential clauses using the same verb, so 'stand', plus a prepositional phrase with ngä; again, in the first clause the PP refers to the source of the motion ('his eye'), whereas in the second clause it refers to the goal ('the bowl'). Again, a significant amount of real-world knowledge appears to be necessary to arrive at this interpretation.

We see, then, that the spatial preposition ngä has a highly schematic meaning, and that often context and real-world knowledge plays a role in determining the kind of spatial relation it is used to refer to. While other spatial-referring 
expressions such as the verb and its accompanying directionals clearly contribute to the interpretation, these alone cannot be taken to fully specify the spatial relations involved, as (2-3) show.

Ngä has a person-marked form used when the preposition takes a pronominal complement; ngâgu 'to me', ngâgumu 'to you', ngâguji 'to you and me', ngâgo 'to him/her' etc. Ngämi functions as a pro-form for prepositional phrases with ngä, illustrated in (4) with an example taken from the same text as (3):

(4) Täpilee iââmä ilâ ponu kâ delaa nyibä lâ kimeputoto ngämi nâ.

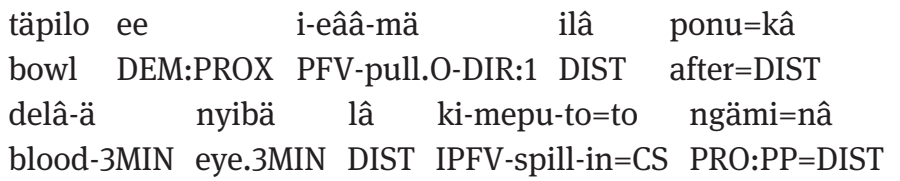

'He pulled the bowl towards him, and then the blood flowed into it.'

The semantics of prepositions is generally described in cognitive linguistics in terms of the concept of a search domain: expressions such as above $X$ or in front of $X$ project a spatial region from a part of the ground object $X$ and instruct the hearer to search for the located object within this region. Hawkins (1981), who introduced the term, states that

all locational (as opposed to path) prepositions are considered to be relations between a particular landmark and a search domain (...). The search domain is designated by the entire prepositional phrase itself. It is a product of the particular relation expressed by the preposition and the specific landmark to which that relation applies (Hawkins 1981: 103).

A schematic preposition like ngä, however, does not specify a "particular relation" and as a consequence cannot really be said to project a search domain. While Äiwoo does have spatial expressions involving search domains, such as the relational nouns described in 2.4, I will argue that a different strategy for locating the Figure relative to the Ground is involved in the constructions discussed in Section 3.

\subsection{Relational nouns}

A number of languages which have only one or a few spatial prepositions express stative spatial relations by means of relational nouns, i.e. nouns with meanings such as 'back (of)', 'top (of)', 'inside (of)', etc. While the term originates in Mayan linguistics (see, e.g. Báez and Bohnemeyer 2008; Brown 1994), relational nouns are also a common strategy in Oceanic languages. Some examples are given in (5): 
(5) a. Soghoru pa kenuna tevolo.

soghoru pa kenu-na tevolo

sit LOC front-ATTR:3SG table

'He is sitting in front of the table.'

(Ughele, Solomon Islands, Frostad 2012: 138)

b. Iñko nēk i le o ñe, nēk i mem siag lēmēèe löt.

$\begin{array}{llllll}\text { in̄ko nēk } & \text { i } & \text { le o } & \text { ne } \\ \text { now } & \text { 2SG } & \text { 2SG.DEF } & \text { take } & \text { COM.ART } & \text { Canarium } \\ \text { nēk } & \text { i } & \text { mem } & \text { siag } & \text { lē=mēēe } & \text { löt } \\ \text { 2SG } & \text { 2SG.DEF } & \text { put } & \text { up } & \text { COM.LOC=top food.dish }\end{array}$

'Now you take the Canarium nuts and you put them on top of the löt food dish.'

(Vurës, Vanuatu, Malau 2016: 372)

c. 'o le lā'au i tua o le fale

'o le lā'au i tua o le fale

PRES ART tree LD back POSS ART house

'the tree behind the house'

(Samoan, Samoa, Mosel and Hovdhaugen 1992: 95)

Äiwoo does have a number of relational nouns, such as, e.g. numângä 'back, behind', numaluwä 'middle, centre', or nyivile 'side'. However, for the particular spatial configurations to be discussed below, namely 'above', 'below', 'inside' and 'next to', relational nouns are generally not used. The noun nupaa translates in some contexts as 'top', and might be thought of as a plausible source for the 'above' relation, but in fact it does not have such a use, although it is frequently used with the meaning 'end', as in nupaa näkenaa 'the end of the story'. Nupä 'mouth' can in some cases be used to refer to the inside space of something, and forms such as nupä nuwopa 'the inside of the house' have been produced in elicitation; but they are rare in texts, and nupä clearly does not function as a generalised 'inside' form. Similarly, nyida 'guts, insides, interior part' is occasionally encountered in combinations such as nyida nelo 'underwater (insides of the sea)', but again this is infrequent and seems to be limited to a few more or less conventionalised combinations.

\subsection{Directional morphemes}

The occurrence of so-called directional morphemes specifying the direction, spatial or metaphorical, of the verbal action is very common in Oceanic 
languages. ${ }^{3}$ Oceanic directionals tend to fall into two types: person-oriented or deictic forms which refer to the participants in the speech situation ('towards speaker or deictic centre', 'towards addressee', 'towards a 3rd person, away from the speech situation') and topological or absolute forms which refer to direction on a vertical axis (up, down) or relative to a landmark or boundary (in, out, across). The latter set also typically has what François (2004) calls geocentric uses, referring, e.g. to direction seawards vs. landwards or against vs. in the direction of the prevailing winds.

The directional system in Äiwoo is fairly typical in these respects. There are three deictic directional suffixes: -mä 'towards 1st person', -wâ 'towards 2nd person', $-k \ddot{a} /-k \hat{a}$ 'towards 3rd person, away'"

a. Itemä.

i-te-mä

PFV-see-DIR:1

'S/he looks at me/us.'

b. Itewâ.

i-te-wâ

PFV-see-DIR:2

'S/he looks at you.'

c. Itekä.

i-te-kä

PFV-see-DIR:3

'S/he looks at him/her/it.'

The deictic directionals do not necessarily refer to the speech situation directly, but can refer to some other deictic centre which is salient in the context; this is frequent in narratives, where a central protagonist may function as the deictic centre. An example of this is seen in (4), where the 1st person directional -mä appears with reference to a 3rd-person participant (iââmä 'he pulled it towards him'); as the person in question is the current focus of the narrative, he functions as the deictic centre and the directional refers to him as such.

Precisely which forms should be included in the category of topological directionals is less clear. Äiwoo makes extensive use of nuclear-layer verb serialisation (Foley and Olson 1985), meaning that verbs frequently occur as manner modifiers to other verbs; there are also forms classified as adverbs which occur in the same

3 By metaphorical direction is meant that an action is construed as directed towards a person if it is performed, e.g. for that person's benefit or on their behalf.

4 A fourth directional suffix, -ngo 'to/towards 1st person', is only used in imperatives. 
position in the verb complex, but lack an attested use as independent verbs. Any such form which indicates a direction of motion and may be used to modify a verb could in principle be classified as a directional, for example ule 'go across', po 'go through' or vili 'go around'. Here we will focus on the four directional forms ee 'up', $(w) o l i$ 'down', to 'in' and lâ 'out'. These can occur as verbs on their own, meaning 'go up', 'go down' etc.; examples for ee and (w)oli are given in (7):

(7) a. Eâunäbä kâ kuweekâ ngä nelo milaki.

eâunäbä=kâ ku-ee=kâ ngä nelo mi-laki

hawksbill=DIST IPFV-up=DIST LOC sea BN-small

'The hawksbill turtle comes up at low tide.'

b. Ikuwoli ngä neio.

i-ku-woli ngä neio

1MIN-IPFV-down LOC hill

'I'm going down from the hill.'

However, they are more commonly found in combination with another verb; with motion verbs, they indicate the direction of the motion as being upward (a), downward (b), inward (c) or outward (d):

(8) a. Siweeväkäja uu mo liamoliwâ.

siwo-ee-väkä=ja uu mo li-eâmoli-wâ

hold-up-a.bit=just high CONJ 3AUG-see.O-DIR:2

'Lift it up a bit so they can see.'

b. Sigiwâu eââ kipääwoli näte.

sigiwâu eââ ki-pää-woli näte

young.man DEM:DIST IPFV-throw-down firewood

'The young man drops off (lit down) firewood.'

c. Eä doo ilâ nyibää lâ kuwoto sii känâ?

eä doo ilâ nyibä ee lâ ku-wo-to

CONJ what DIST basket DEM:PROX DIST IPFV-go-in

$\mathrm{sii}=\mathrm{kä}=\mathrm{nâ}$

fish $=\mathrm{CV}=\mathrm{DIST}$

'And what kind of basket [is used] for the fish to go into?'

d. Kitevetokäde go nyivepe eä dewolâeo.

ki-teve-to-kä-de

go nyi-vepe eä

IPFV-line-in-DIR:3-1+2AUG CONJ NMLZ-hot of.3MIN

de-wo-lâ=eo.

EVIT-go-out=PROH

'We put stones around it so the heat doesn't leak out.' 
As in other Oceanic languages, the topological directionals also have geocentric uses, but these will not be discussed here; the remainder of this paper will focus on the use of directionals in expressions of stative spatial relations.

\section{Directionals and stative spatial relations}

\subsection{The semantics of the stative relation construction}

The construction with which this paper is primarily concerned typically combines a verb of position or placement (e.g. ko 'lie', tokoli 'sit', so 'stand' or mo 'stay, live') with a topological directional and a deictic directional in order to express a stative spatial relation between the located entity, i.e. the subject ${ }^{5}$ of the verb, and some other entity. Consider the following example, from a text about a young man who is caught in a terrible storm while out fishing in his canoe, and drifts ashore on an unknown island where he sees a sailing canoe lying in a spot higher up on the beach:

(9) Basikieekänâ lâto känä kisokoueekä ngäminâ.

basiki-ee-kä=nâ lâto kä=nä ki-so-kou-ee-kä
run-up-DIR:3=DIST then say=CV IPFV-stand-hide-up-DIR:3
ngämi=nâ
PRO:PP=DIST
'He ran up, wanting to shelter underneath [the canoe].'

This example shows two instances of a verb followed by the directional combination ee-kä 'up-towards 3rd person'. With the motion verb basiki 'run', the directionals have the expected reading: the protagonist runs upward and in the direction of a 3rd-person entity, the canoe. With so 'stand', on the other hand, the meaning is rather different. so-kou-ee-kä here means 'stand hiding underneath'; that is, the protagonist is neither moving 'up' nor located 'up' with respect to the Ground object, the canoe. In fact, the opposite is the case: the canoe is located 'up' with respect to the man. This is not a random fluke but a

5 I use the term 'subject' here for ease of exposition, though I have argued elsewhere that 'subject' is not necessarily a useful analytical category for Äiwoo (Næss 2015). However, the issues surrounding the organisation of clausal relations are of no relevance to the phenomena discussed here, and so 'subject' will be used here for the argument obligatorily indexed by person-markers on the verb (note that 3MIN arguments are usually zero-marked). 
completely systematic effect of the combination ee 'up' + deictic directional used with a verb of location and position; more examples are given in (10):

a. mikiliemoeekä ngâ nâbongä

mi-ki-li-e-mo-ee-kä

ngä nâbongä

BN-IPFV-3AUG-PREF-stay-up-DIR:3 LOC upper.arm.3MIN

'those that are underneath him (lit. under his arm)'

b. Danyige kiseekä ngä nyetââ.

danyige ki-so-ee-kä

ngä nye-eotââ

coconut.leaf.mat IPFV-stand-up-DIR:3 LOC place-see.reflection

'The [rolled-up] mat is standing underneath the mirror.'

c. Kipaapoiwolingopu lâto kiteemäto ngâ nubo ngä lâ negi eângâ.

ki-paapoi-woli-ngopu lâto ki-to-ee-mä=to

IPFV-plant-down-1AUG thus IPFV-be-up-DIR:1=CS

ngä nubo ngä negi eângâ

LOC ground LOC mound DEM:DIST

'We plant it, so it is under the ground, in those mounds.'

Example (10a) describes the relationship between the highest-ranking chief in the traditional village power structure and the lower-ranking chiefs. The lowranking chiefs, the subject of the relative-clause-like structure mikiliemoeekä 'the ones who stay up towards' are not located 'up' with respect to the high-ranking chief, or his arm; it is the high chief who is 'up' relative to the lower chiefs. (10b) was produced as the response to a request to describe the location of a rolled-up mat standing on end underneath a mirror hanging on the wall; again the mat is not 'up' relative to the mirror, but rather the other way round. And in (10c), the root crops in question, having been planted, are underneath the ground, not over or above it. We see, then, that the combination of ee 'up' plus a deictic directional (-kä in all these examples, though see 3.4 ) is consistently used to encode the meaning 'below, underneath'.

In a completely parallel fashion, $(w)$ oli 'down' + deictic directional with a verb of location or position means 'above, on top of':

(11) a. Mo inâ le kooluutekä mo nyibe lä ngä negi länâ.

Mo inâ le ko-oli-ute-kä mo nyibe lä

CONJ 3MIN PROX lie-down-again-DIR:3 with wrapping of.3MIN

ngä negi lä=nâ

LOC mound of.3MIN=DIST

'And he was lying again with his shroud on top of his grave.' 
b. Bolo momalâ ilâ kitokoliwoliwâ ngâ nupää kâ.

bolo momalâ ilâ ki-tokoli-woli-wâ
ball dark.blue/green DIST IPFV-sit-down-DIR:2
ngâ nupää=kâ
LOC cloth=DIST
'The blue ball is sitting on top of the cloth.'
Totokale kitäveolikä ngä namââ.
totokale ki-täve-oli-kä nä namââ
picture IPFV-hang-down-DIR:3 LOC platform
'The picture is hanging above the bed.'

Example (11a) deserves comment in that 'lie down' in languages such as English can be used inchoatively, i.e. to refer to the act of assuming a lying position. However, in Äiwoo stative and inchoative position verbs behave rather differently in combination with certain topological directionals, as will be discussed further in 3.6, and kooliutemä in (11a) clearly refers to being in a lying position on top of something, rather than assuming such a position: the example refers to a man who has died and been buried, but when his relatives return to the grave a few days later, they find him lying on top of it again. Clearly, then, the grave is 'down' with respect to the dead man, not the other way round. Similarly, in (11b) the ball is placed on top of the cloth, i.e. the Figure is located in an upwards direction relative to the Ground; while in (11c), it is the bed that is 'down' relative to the picture rather than the other way round.

Note moreover that this construction does not distinguish situations where the Figure is in contact with the Ground from situations where it is not; in (11ab) the Figure is in contact with and supported by the Ground, whereas in (11c) there is no contact. The same appears to hold for (9-10), where (10c) and probably (10a) involve contact between Figure and Ground, while (9) and (10b) do not.

A similar effect is seen with lâ 'out', which in combination with a deictic directional with the same set of verbs means 'inside'; the Ground can be a container (12a-b) or an enclosure (12c):

(12) a. Eâmo lâ kâlâ lâ kolâmä ngä nupo.

eâmo lâ kâlâ lâ ko-lâ-mä ngä nupo

CONJ DIST there DIST lie-out-DIR:1 LOC net

'And then it [the turtle] lies in the net.'

b. Le kivevägilelämä ngä täpileenge.

le ki-vevägile-lâ-mä ngä täpilo enge

PROX IPFV-wriggle-out-DIR:1 LOC bowl DEM:PROX

'[The baby] was wriggling inside the bowl.' 
c. Bolo momalâ kitokolilämä ngä nyeele eä nuwale.
bolo momalâ
ki-tokoli-lâ-mä
ngä nyeele eä nuwale
ball dark.blue/green
IPFV-sit-out-DIR:1 LOC coil
of rope
'The blue ball is sitting inside the coil of rope.'

Finally, and perhaps somewhat less strikingly, to 'in' with a deictic directional and a verb of position or location means 'next to' or 'against':

(13) a. Iobolimä ngä nyenaa ilâ kisotokä ngâ nuwopa tä nâ.

i-oboli-mä ngä nyenaa ilâ ki-so-to-kä

PFV-fall.down-DIR:1 LOC tree DIST IPFV-stand-in-DIR:3

ngâ nuwopa tä=nâ

LOC house POSS:LOC=DIST

'It fell down from a tree that stood next to his house.'

b. Mekimeitokäle ngâ nuwo nyenaa.

me-ki-mei-to-kä-le ngâ nuwo nyenaa.

1AUG-IPFV-sleep-in-DIR:3-UA LOC base tree

'We will sleep by the bottom of a tree.'

\subsection{Stative spatial relations and fictive paths}

In a striking way, these constructions seem to reverse the meaning of the topological directional: 'up' occurs in forms meaning 'underneath', 'down' in forms meaning 'above', and 'out' in forms meaning 'inside'. This effect is perhaps less obvious with to 'in', but it is clear that to + DIR 'next to, against' does not involve the figure being or moving inside the ground object in any way, cf. the canonical meaning of to illustrated in (8c).

How is this situation to be interpreted? One possibility is that this is an instance of so-called Figure-Ground reversal, where the relation is construed with respect to the Ground object's location relative to the located entity rather than the other way round (Talmy 2000; Thiering 2011). However, this seems like an unsuitable analysis, for at least two reasons. Firstly, Figure-Ground reversal is typically conceived of as an optional process that shifts the perspective on a spatial scene, as in The car is next to the tree vs. The tree is next to the car. In Äiwoo, however, this is not an optional reversal but the default way of expressing the relation in question. Moreover, there is no reversal of perspective, if this is taken to mean that that the expression locates the Ground object, in the sense of the referent of the ngä phrase, relative to the subject argument of the verb rather than the other way round. (9) clearly locates the man with respect to the 
canoe, (10a) the lower-ranking chiefs with respect to the high-ranking chief's arm, (11a) the dead man with respect to the grave, (10c) the root crops with respect to the mound, etc.

An alternative analysis is that these constructions involve what Talmy (1983, 2000) refers to as fictive motion. None of the examples involve actual, physical motion; the Figure remains in a fixed location. In the words of Talmy (2000: 104), however, "languages systematically and extensively refer to stationary circumstances with forms and constructions whose basic reference is to motion". That is, we can think of the stative relation ' $\mathrm{X}$ is below $\mathrm{Y}$ ' as being mapped onto a metaphorical path where $\mathrm{X}$ is construed as moving towards $\mathrm{Y}$; if $\mathrm{X}$ is below $\mathrm{Y}$, then this metaphorical motion will be in an upwards direction, whereas if $\mathrm{X}$ is above $Y$, the metaphorical motion is in a downwards direction. At the same time, the semantics of the main verb ensures that the construction is not interpreted as denoting physical motion.

Matlock (2004) notes that fictive motion constructions need explicit reference to a landmark; while English sentences such as The road runs along the coast or The railroad tracks follow the river are unproblematic, ?The road runs or ?The railroad tracks follow are highly problematic. From this perspective, the function of the deictic directional in the Äiwoo stative relation construction can be understood as providing explicit reference to the Ground (Matlock's 'landmark') within the verb complex; as long as the directional is present, the prepositional phrase referring to the Ground can be omitted, following the general tendency in Äiwoo, as in Oceanic languages in general, to omit referential phrases such as arguments or local adjuncts where their reference is retrievable from context.

Figure/Ground organisation is essential to the coding of relational predications (Langacker 1987: 231); that is, in describing a stative spatial relation, one of the two entities entering into the relation must be picked out as the entity that is to be located with respect to the other. Langacker notes (1987: 234) that "That verbs of physical motion and activity are commonly recognized as prototypical may be due in part to the clear basis they provide for determining figure/ground alignment”. In other words, equating the Figure in a stative relation with the moving entity in a motion scenario may be cognitively natural; casting the Figure as the subject of a motion construction is a means of indicating its status as the Figure as opposed to the Ground. If a language lacks prepositions explicitly encoding differences in Figure/Ground relations, such as above vs. below, such differences must clearly be encoded in some other way; the Äiwoo data seems to indicate that a possible alternative is the encoding of the Figure as the subject of a motion expression. 
For the individual constructions exemplified above, this analysis provides the following account: ee + DIR is interpreted as meaning 'below, underneath' in a stative construction because if a Figure is moving upwards towards a Ground, this means that the Figure is currently below the Ground, as with, e.g. the boy 'standing up towards the canoe' in (10). Similarly, (w)oli + DIR gets the reading 'above' because a Figure moving down towards a Ground must currently be above the Ground.

la + DIR 'inside' can be understood from the same perspective if we consider that the prepositional phrase in these cases refers to some type of container or enclosure. If something is moving out relative to a container or enclosure, then by inference it is currently inside it. And with to + DIR, for a Figure to be moving in towards a Ground can be taken to mean that it is close to, next to or up against that Ground. The precise role of the deictic directionals in these constructions will be discussed further in 3.4.

I propose, then, that the directional stative-relation construction in Äiwoo is best understood as an instance of fictive motion, where the Figure is seen as figuratively moving towards the Ground. This is in line with what Talmy (2000: 171) calls the "cognitive bias towards dynamism" in language, where stationary phenomena tend to be represented linguistically by means of motion expressions; or, as Talmy puts it, "the mapping of motion as a source domain onto stationariness as a target domain”. It seems reasonable that a language like Äiwoo, with a large inventory of lexical items referring to direction of motion and a very small inventory of items referring to stationary location, would exploit this bias systematically in the domain of stative spatial relations. The chicken-and-egg question of whether it is the underlying cognitive bias that allows for the lexicon to be organised in this way, or whether the organisation of the lexicon provides the resources for the speakers to exploit the bias to a greater extent than in other languages, is of course impossible to answer in any principled way. However, a parallel, though more restricted construction in the Oceanic language Caac of New Caledonia may shed some light on how the Äiwoo stative relation construction may have arisen.

\subsection{Anticipated path constructions in Caac}

Cauchard (2014, ms) analyses several constructions using topological and deictic directionals in the Oceanic language Caac (New Caledonia) as involving fictive motion. In the current context, the most interesting is the construction Cauchard labels “Anticipated Path”, as in (14): 
(14) da=me Kareon.

be.at.3SG upward=CENTRIP Kareon

'She is down (lit. 'up towards us') at Kareon.'

(Caac, Cauchard 2014: 276)

Cauchard describes this construction in terms of a fictive path which the Figure is required to follow in order to reach the deictic centre, the location of the speech-act participants. The construction

\begin{abstract}
locates the Figure and implies that this location is momentary: it is one point on a journey undertaken by the Figure. It indicates that the Figure is expected to come back to the initial place (the speech-act participant's location) ... In [14], the Figure has left her place (where the speech-act participants are) to go into the mangrove swamp to fish crabs; the implicature is that she is expected to come back home a few hours later. The return journey is anticipated through the use of the directionals. Such expressions display two distinct elements: a temporary location encoded by the spatial phrase (e.g. Kareon in [14]) and a journey towards the Deictic Centre (always identified with the speech-act participants in the examples collected up to present). (Cauchard 2014: 277).
\end{abstract}

There are striking parallels between the Äiwoo stative-location construction and the Caac Anticipated Path construction. The Caac construction, like the Äiwoo one, obligatorily involves a combination of a topological and a deictic directional (the directional in [14] denoting direction towards the deictic centre is glossed 'centripetal' by Cauchard), and appears to reverse the direction of the topological directional; just like I have proposed for Äiwoo, Cauchard analyses this in terms of a fictive path to be followed by the Figure in order to arrive at the Ground.

There are, however, also crucial differences. The Caac construction appears only to involve the verbs $e$ 'be at' and mo 'stay, live', whereas the Äiwoo construction is used with a wide variety of verbs (cf. 3.5 below). As is evident from the quote above, the Ground in the Caac construction is always the deictic centre, whereas the Äiwoo construction typically specifies a Ground through a prepositional phrase. Note the difference between the Caac example in (14), where the locative phrase Kareon specifies the current location of the Figure rather than the endpoint of the fictive path, and Äiwoo examples (9-13) where the $n g a ̈$ phrase represents the Ground for the fictive motion event. And the Caac construction is restricted to Figures that are animate or moveable (Cauchard 2014: 286) - i.e. Figures that can be expected to move towards the deictic centre at some point, even though they are currently stationary. It is the latter point especially which lends credibility to Cauchard's "Anticipated Path" analysis the path is viewed as part of a larger motion event, where the Figure has moved away and will at some point return. 
As already noted, the Äiwoo stative-location construction has a much wider domain of use, and is not restricted either to moveable Figures or to the deictic centre as Ground. Given the formal and functional similarities, however, the Äiwoo construction may have developed through generalisation from a construction similar to that found in present-day Caac. The Caac construction shows how stative location and fictive motion can be conceptually linked through the notion of a temporary location as part of a return journey, and how this can be encoded through the use of a combination of topological and deictic directionals. If the 'return journey' aspect of the semantics is lost, and the construction extended to allow non-moveable Figures and other Grounds besides the deictic centre, this would give something very similar to the present-day Äiwoo system.

It is difficult to posit a direct historical link between the Caac construction and the Äiwoo one, as the two languages belong to different branches of the Oceanic family; Äiwoo is classified as belonging to the Temotu subgroup (Ross and Næss 2007) whereas Caac by traditional classifications belongs to a fairly low-level grouping within the Southern Oceanic linkage (Lynch et al. 2002: 113). However, the region is assumed to have been settled rather rapidly, and Hammarström et al. classify the New Caledonian languages as a branch of "Southern Melanesian" which in turn is posited as a first-order subgroup on the same level as Temotu. Grammatically, Äiwoo is in some respects very conservative, retaining among other things a symmetrical voice-type system which was previously thought to have been lost already in Proto Oceanic (Næss 2015). It is thus possible that Äiwoo and Caac both retain reflexes of a construction that was present in Proto Oceanic; while it is striking that these languages are the only two for which such a construction is reported, the level of description for Oceanic languages varies greatly, and similar constructions in other languages may well have been overlooked.

\subsection{Deictic directionals in the Äiwoo stative-location construction}

As noted above, Caac restricts the Ground in the Anticipated Path construction to the deictic centre, whereas no such restriction is apparent in Äiwoo. However, there is some evidence to suggest that the Äiwoo construction makes reference to the deictic centre as a default Ground, even though other Grounds are possible.

As is apparent from the examples given above, some combinations of topological directional and deictic directional are considerably more common 
than others in the stative-location construction. Specifically, ee 'up' and to 'in' combine most frequently with -kä 'DIR:3', whereas (w)oli 'down' and lâ 'out' combine most frequently with -mä 'DIR:1'. However, other combinations are clearly possible, as illustrated by examples such as (10c) and (11).

The preferences make sense under a fictive-motion analysis if the default reading is taken to refer to a deictic centre which is construed as being located at ground level and non-contained. In such a scenario, fictive motion upward and inward (into a container) takes place in a direction away from this deictic centre, hence the use of - $k \ddot{a}$ 'towards 3rd person, away', whereas motion downward and outward from a container takes place in a direction towards the deictic centre, referred to by -mä 'towards 1st person'. This analysis is supported by examples such as (10c), where the fictive motion takes place upwards from an underground location; in this case, the deictic directional chosen is -mä, which is to be expected if the default deictic centre is construed as being located at ground level.

Other exceptions may involve a more direct reference to the speech situation as opposed to a default deictic centre. For example, in the elicited example (11c), the picture and bed in question were located at some distance from the speech situation, so that -mä 'toward 1st person' may have been less natural than if, say, the speaker had been sitting on the bed. Clearly a number of factors are relevant here, but the fact that clear preferences exist, all other things being equal, suggests a default interpretation in terms of motion away from or towards the deictic centre.

This raises the question of how the different spatial morphemes involved in this construction contribute to the semantics of the whole. The topological directional, the deictic directional and the preposition ngä all relate a Figure to a Ground; the question is whether they are all coreferential in relating the same Figure to the same Ground.

It seems clear that all three forms share the same Figure, i.e. they locate the same entity with respect to some Ground. Whether they all relate this entity to the same Ground is less obvious, as suggested by the proposal that the deictic directional may by default refer to the deictic centre. This is clearly not the case for the topological directional and the preposition, which do share the same Ground; the topological directional describes the Figure's fictive motion towards the complement of the preposition, e.g. up towards the canoe (9), down towards the bed (11b), or in towards the tree (13b). When the complement of $n g \ddot{a}$ is a 3rd-person entity and the deictic directional used is the 3rd-person form $-k \ddot{a}$, it is not obvious whether the Ground for the directional is the entity specified in the prepositional phrase ('in the direction of the canoe/bed/tree') or the deictic centre ('away from the deictic centre'), as the two directions 
overlap. When another deictic directional is used, however, this overlap does not occur, and this suggests that the deictic directional in fact relates to a different Ground than the other two spatial morphemes, namely the speech situation.

\subsection{Non-position verbs}

The discussion so far has centered on verbs of position and location, though a few of the examples given show verbs which do not strictly speaking seem to fit this description, such as vevägevile 'wriggle' in (12b) and mei 'sleep' in (13b). Indeed, any verb which does not directly lexicalise motion can appear in this construction, with the meaning that the activity in question takes place in the indicated location. The following (elicited) examples show how, with the verb vängä 'eat', a topological directional on its own indicates the direction in which the action is carried out, while the combination of a topological and a deictic directional indicates that the action is taking place in a given location relative to a reference point, in this case the speaker:

\section{(15) a. Kivängäee.}

ki-vängä-ee

IPFV-eat.A-up

'S/he is eating from up high (eating upwards).'

b. Kivängäolimä.

ki-vängä-oli-mä

IPFV-eat.A-down-DIR:1

'S/he is eating up there.'

In (15a), the food is located higher than the eater, so that the act of eating itself is being carried out in an upward direction - the person eating has to reach upwards to carry out the act. In (15b), on the other hand, the whole act of eating is taking place in a location higher than the speaker; there is no implication that the act itself is being carried out in a particular direction. These examples underscore, firstly, that it is the combination of topological directional and deictic directional that gives the stative-relation reading, and secondly, that the construction is highly productive and can be used with a wide range of verbs to indicate a stative spatial relation between two entities, as opposed to the restricted domain of the Caac Anticipated Path construction. 


\subsection{Inchoative vs. stative posture verbs}

Many of the examples in 3.1 involved the posture verbs ko 'lie', tokoli 'sit', and so 'stand'. These are all verbs which refer to the state of being in a particular posture, i.e. 'be in a lying position', 'be in a sitting position', 'be in a standing position'. If we look at what we may call inchoative posture verbs, i.e. verbs denoting the act of assuming a particular posture, we see a strikingly different pattern.

The inchoative posture verbs obligatorily include a directional component, which in my data is restricted to 'up' or 'down': kee/kooli 'assume a lying position (up/down)', ' tää/tââli 'assume a sitting position (up/down)', liää 'assume a standing position'? No corresponding 'down' form is attested for liää 'stand up' which is not unexpected given that the act of assuming a standing position normally implies upward motion.

The stative position verbs ko 'lie', tokoli 'sit', and so 'stand', on the other hand, do not require a directional, as examples (16a-c) show.

(16) a. Nyânou nyigi itekäile kiko.

nyâ-nou nyigi i-te-kä-i-le ki-ko

tree-banana one PFV-see-DIR:3-3AUG-UA IPFV-lie

'They saw a banana tree lying [on the road].

b. Ikitokoli mo pelivanoungopu.

i-ki-tokoli mo pelivanou-ngopu

1MIN-IPFV-sit with children-1AUG

'I was sitting with our children.'

c. So ile ngä nyenge.

so ile ngä nye-enge

stand PROX LOC place-DEM:PROX

'Stand here.'

With the inchoative verbs, the forms in ee 'up' can refer to coming into a position in a high location (my only examples are with kee 'lie up'):

6 Note that $k o+(w)$ oli can have a stative as well as an inchoative reading, cf. (11a).

7 The final -ää suggests a process of sandhi where ee is added to a root ending in â [a], cf. delâ 'blood' delâ + ee>delää 'this blood' (ee 'proximal demonstrative'). Although no root 'stand up, rise' without ee is attested, it is a reasonable assumption that liää 'stand up, rise' includes a component ee 'up', cf. the contrast between tää 'sit up' vs. tââli 'sit down', where the form of the latter suggests a root-final â + woli. 
(17) Ee, maa nulou lâ likee nâ ilâ ... ilâkâ lâ iväpoulâto.

\begin{tabular}{|c|c|c|c|}
\hline maa & nulou & lâ & li-ko-ee=nâ \\
\hline & small.leafed.sago & DIST & 3AUG-lie-up=DIST \\
\hline & lâ & & \\
\hline $\mathrm{ST}=\mathrm{DIST}$ & T DIST PFV-finish & $\mathrm{h}=\mathrm{CS}$ & \\
\hline
\end{tabular}

'Yes, when the leaf panels have been laid up (on the rafters, as part of the roof), then [the house] is finished.'

However, they are also used to refer to the act of assuming a position on top of a ground object:

(18) a. Kee ngâ nämââ.

ko-ee ngä nämââ

lie-up LOC platform

'Lie on the bed.'

b. Lâ imelekänâ itää ngä nyimä.

lâ i-mele-kä=nâ i-tâ-ee ngä nyimä

DIST PFV-fly-DIR:3=DIST PFV-sit-up LOC hand.3MIN

'(The bird) came flying and sat on her hand.'

Liää 'stand up' differs from kee 'lie up' and tää 'sit up' in this regard, as it does not imply a resultant configuration with a ground object:

(19) Kililiäädukaa kulupwä ngä belo.

$\begin{array}{lll}\text { ki-li-liää-du=kaa } & \text { ku-lu-pwä ngä belo } \\ \text { IPFV-3AUG-stand.up-all=FUT } & \text { IPFV-3AUG-go } & \text { LOC bell } \\ \text { 'They'll all stand up and go to the church.' } & \end{array}$

This is likely due to the semantic differences between the verbs: while assuming a lying or a sitting position typically implies coming to rest in a particular location, assuming a standing position, by contrast, implies removing oneself from a location in which one was previously settled, and is often the precursor to motion.

What is striking, however, is that the effect of ee in the cases where a resultant configuration is entailed (examples 18a-b) is exactly opposite with the inchoative posture verbs vs. the stative posture verbs: with the inchoative verbs, ee locates the Figure on top of the Ground, whereas with the stative verbs, it locates it below or underneath it, as seen in examples (9)-(10). 
That is, ee 'up' has a very different function in motion constructions with a resultant configuration than it has in stative spatial constructions: in the former, it means 'on top of', whereas in the latter it means 'underneath'. This contrast is only found with ee 'up'; while kee 'lie up' and tää 'sit up' mean 'lie down on' and 'sit down on' respectively, kooli 'lie down' and tââli 'sit down' do not similarly specify a resultant configuration but simply the direction of motion:

(20) a. Livängä, ä liekooli, lâ kilimeikâ.

$\begin{array}{lllll}\text { li-vängä } & \text { ä } & \text { li-e-ko-oli } & \text { lâ } & \text { ki-li-mei=kâ } \\ \text { 3AUG-eat } & \text { CONJ } & \text { 3AUG-PREF-lie-down } & \text { DIST } & \text { IPFV-3AUG-Sleep=DIST }\end{array}$

'They ate, and lay down, and slept.'

b. Itââli lâto kivängäkâ.

i-tâ-woli lâto ki-vängä=kâ

PFV-sit-down thus IPFV-eat=DIST

'He sat down and ate.'

This pattern is found not only with inchoative posture verbs, but also with other verbs which refer to the motion of an object into a spatial configuration with another object. In the following, I will examine two types of such verbs: verbs of vertical motion and verbs of placement.

\subsection{Verbs of vertical motion}

With verbs of vertical motion, the addition of a topological directional normally serves to indicate the direction of motion:

(21) a. Nupâwâ lä näte lâ ibuliwoliwânongâ.

nupâwâ lä näte lâ i-buli-woli-wâ-no=ngâ.

bundle of.3MIN firewood DIST PFV-topple-down-DIR:2-1MIN=DIST 'I dropped the bundle of firewood there.'

b. Lâto vili iluweetowâ, lâto kimelekâ.

lâto vili i-luwo-ee=to=wâ, lâto ki-mele=kâ.

thus parrot PFV-jump-up=CS=DIST thus IPFV-fly-DIST

'Then the parrot jumped up and flew away.' 
However, when the motion results in a stative spatial relation between the Figure and a Ground object specified in a ngä phrase, ee 'up' is used to refer to this resulting relation rather than to the direction of motion:

(22) a. Eâmo tololo wä sime minuboto lâ mepueetowâ ngâgonâ.

eâmo tololo wä sime mi-nubo=to lâ

then rot.liquid of.3MIN person $\mathrm{BN}$-die=CS DIST

mepu-ee=to=wâ ngâgo=nâ

spill-up=CS=DIST to.3MIN=DIST

'And liquid from the dead man dripped down on him.'

b. Tememe kuwomaa lâ kiebueekâ ilâ ngä nyimeilâ.

tememe ku-wo-maa lâ ki-ebu-ee=kâ

baby IPFV-go-DIR:1 DIST IPFV-fall-up=DIST

ilâ ngä nyime-i=lâ.

DIST LOC hand-3AUG=DIST

'When the baby comes (=is born), it falls onto their hands.'

In (22a), the liquid does not drip upwards, and in (22b), the baby when born does not fall upwards. Rather, ee here indicates the resultant spatial relation: the liquid falls on top of the protagonist, and the baby falls onto the midwife's hands. Note that here, as with the inchoative posture verbs, the "reverse" effect seen in 3.1 does not hold; the baby is 'up' relative to the hands, and this is indicated with ee, not with woli.

\subsection{Verbs of placement}

Verbs of placement, typically translating into English with verbs such as 'put' or 'place', show considerable complexity in Äiwoo. We will focus here on a set of forms which are morphologically complex and built around the directional verbs ee 'up', (w)oli 'down', to 'in' and lâ 'out'.

The forms distinguish between placing something in a sitting, standing or lying position, although this distinction is neutralised when the verb refers to a plurality of entities being placed. All forms show the causative prefix $w \hat{a}^{-}$, and the forms for 'place in a sitting position' and 'place in a lying position' appear to include the roots te 'sit' and ko/ku 'lie', i.e. 'cause to sit upwards', 'cause to lie downwards' etc. Because the exact structure of these forms is in many cases difficult to analyse, they are not segmented in the examples below, but simply glossed as a whole. The relevant forms are given in (23): 
(23) a. wâkie 'put up lying' wâkuwoli 'put down lying'

wâkito 'put in lying' wâkilâ 'put out lying'

b. wâtee 'put up sitting' wâtooli 'put down sitting' wâteto 'put in sitting' wâtelâ 'put out sitting'

c. wâie 'put up standing' wâiwoli 'put down standing' wâito 'put in standing' wâilâ 'put out standing'

d. wâlie 'put multiple objects up' wâluwoli 'put multiple objects down' wâlito 'put multiple objects in' wâlilâ 'put multiple objects out'

The 'put up' forms can be used to denote placing something in a high location, as in (24):

(24) Eâmo nugulu eââ iwâkiemu.

eâmo nugulu eââ i-wâkie-mu

then drying.net DEM:DIST PFV-put.up.lying-2MIN

'Then you put the net up (above the fire).'

However, they are also commonly used to mean 'put X onto Y', where the placed object does not necessarily move upwards or end up in a higher location than where it started:

(25) a. Dekipongäwâu nyopwä kâ (...) eä wâleekä näte. de-ki-pongä-wâu nyopwä=kâ eä 1+2AUG-IPFV-light.oven-first earth.oven=DIST CONJ wâlie-kä näte put.up.PL-DIR:3 firewood 'First we light the earth oven (...) and put firewood onto it.' (the earth oven is a hole in the ground, i.e. no upward movement is involved) 
b. Lâ singedâ ee itulâmänâ nuwo wä books wâlie ngä tebol.

lâ singedâ ee i-tu-lâ-mä=nâ

DIST woman DEM:PROX PFV-bring-out-DIR:1=DIST

nuwo wä books wâlie ngä tebol

heap of.3MIN books put.up.PL LOC table

'This woman brought a pile of books and put them on the table.' (description of a video clip; the books clearly move downward from the standing woman's arms to the table)

c. Nyipaa kivängâi kuwâlieilâ ngâ nugonuwä.

nyipaa ki-vängâ-i ku-wâlie-i=lâ

shaving PFV-scrape-3AUG IPFV-put.up.PL-3AUG=DIST

ngâ nugo-nuwä

LOC leaf-cutnut

'They would scrape off the bark and put it on a cutnut leaf.'

The examples in (25) do not involve upward motion of the placed object. Rather, $e e$ here has the same function as with the inchoative posture verbs discussed in 3.6 and the verbs of vertical motion discussed in 3.7: it refers to the final configuration of the placed object with respect to some ground, rather than to its direction of motion.

There are two questions to be addressed here. Firstly, how the meaning 'be located on/on top of arises from the basic motion meaning, and secondly why this 'resultant position' meaning appears to arise only with ee, not with the other topological directionals. The question of how the function of ee in this construction is to be reconciled with that described in 3.1-2 will be discussed in 3.9 below.

The relation between 'up' and 'down' is not completely symmetrical. In the words of Cablitz (2006: 378), “The absolute vertical UP/DOWN axis only has one (physical) anchor point, which is the ground location or soil: there is no fixed location which is opposed to the ground location". That is, motion downwards has a natural endpoint, the ground level, whereas motion upwards lacks such an endpoint.

Given the constraints of the physical world, the default position for any inert object is at ground level. If something is located above ground level - and not holding itself up through the use of wings or some other means of propulsion two inferences can be drawn: firstly, that it has been moved there from a lower level, and secondly, that it is supported by something, as otherwise it would drop back down to ground level. On this basis, the pragmatic inference from 'being moved upward' to 'being supported by something, i.e. being on a supporting object' seems quite natural. 
This further explains why we do not appear to find similar constructions involving the other topological directionals. The only other directional for which a similar inference might be argued to hold is to 'in': if an object is moved into some object, then clearly it ends up inside that object, so a resulting configuration could be said to be implied. But this relation is part of the semantics of to to begin with, as moving something 'in' implies the existence of a Ground object that is the goal of the motion, whereas no such object is implied for ee 'up'; therefore, the inference involved with to is of a different nature than with ee. With woli 'down' and lâ 'out' there is no parallel inference; all that can be inferred from an object's being moved 'down' is that it is now in a lower location than previously, and moving something 'out' only implies that a previous 'inside' relation no longer holds.

Woli can, however, be used as the "reverse" of ee in the sense of undoing the spatial configuration implied by ee: where ee can mean 'put onto', (w)oli can be used to mean 'take off of', i.e. remove an object from its location on top of something else:

(26) Teväivä ile kuwâliwolinotowâ ikävooli go ikiebi.

teväivä ile ku-wâliwoli-no=to=wâ

stone PROX PFV-put.down.PL-1MIN=CS=DIST

i-käve-woli go i-ki-ebi

1MIN-remove.stones-down CONJ 1MIN-IPFV-bake.A

'Now I take the stones off (from the earth oven), I remove them so I can bake.'

As noted in the discussion of example (25a), an earth oven is located on and under ground level, so very little in the way of downward motion is implied here; rather, the stones are removed from their location on top of the oven.

\subsection{The goal bias}

We have seen that with verbs of position and location, such as so 'stand' or mo 'live, stay', the directionals ee 'up' and (w)oli 'down' describe the location of a Figure relative to a Ground, in such a way that ee is used when the Figure is located below the Ground, while (w)oli is used when the Figure is located above the Ground; I argued that this could be understood in terms of fictive motion of the Figure in the direction of the Ground. With motion verbs, on the other hand, if there is a conflict between the direction of motion and the resultant spatial relation between the Figure and the Ground, a topological directional is used to 
indicate the resultant relation, and here ee is used when the Figure is on top of the Ground, i.e. above it and in contact with it. The latter pattern was also seen with verbs of placement, which encode a caused spatial configuration between Figure and Ground.

This leaves us with the somewhat paradoxical analysis that ee 'up' is used to indicate (fictive) motion with position verbs, but position with motion verbs. How can this be explained? In 3.2 I referred to a general bias towards dynamism in language, and suggested that this accounts for the fictive-motion construction which construes stative spatial relations as motion of a Figure towards a Ground. There is, however, a second cognitive-linguistic bias which arguably competes with the bias towards dynamism in certain specific cases, namely the goal bias or source-goal asymmetry, where goals appear to be cognitively more salient than sources in a motion event.

The goal bias in language is expressed in a number of different ways. For example, Freeman et al. (1980) show that children find it easier to understand questions concerning where an object has gone to than where it has come from. Children and adults express Goal paths (e.g. 'to the car') more frequently and systematically than Source paths (e.g. 'from the house') in experiments (Lakusta and Landau 2005). Speakers of English, Chinese and Arabic made finer semantic distinctions in descriptions of event endpoints than of event beginnings (Regier and Zheng 2007). Regier and Zheng (2007: 706) suggest that "Once a person has seen a spatial event, the resulting final spatial configuration is more recent in memory than the rest of the event, and is thus more accessible and salient".

This increased salience of the resulting configuration relative to the rest of a motion event seems to be exactly what is reflected in the Äiwoo motion expressions discussed in 3.6-3.8, where ee 'up' is used to describe the resulting configuration rather than the direction of the motion event itself. That is, if a resulting spatial relation is specified with a motion verb, it overrides the direction of motion when the two conflict. Given the existing evidence of a goal bias in language, this is not unexpected. In Äiwoo, however, the fact that this construction contrasts with another construction involving some of the same linguistic expressions but driven by a different cognitive bias, the bias towards dynamism, makes the resulting pattern of distribution and function look rather striking: ee 'up' can mean either 'underneath' or 'on top of', depending on the construction in which it appears. Crucially, the reading 'underneath' only arises in contexts that allows for a fictive-motion reading; when actual, physical motion is involved, this reading does not arise. Instead, the goal bias, combined with the pragmatic inference that if an object that has moved 'up' and is now stationary, it must be supported by something, gives rise to the 'on top of' reading. The interpretation thus depends on both the semantics of the 
verb - whether or not the verb refers to a motion event -; the situation as a whole, i.e. whether, in the case of a motion event, a resulting configuration is encoded or not; and the presence or absence of a deictic directional, which is an integral part of the stative construction. The interactions between these different components are crucial to making the relevant distinctions; for example, with a motion verb the deictic directional simply indicates direction of motion towards a speech-act participant (cf. the examples in [6]), and it is only in combination with a non-motion verb and a topological directional that the stative reading arises. The topological directionals, in turn, have very different functions depending on the construction that they appear in, with ee 'up', in particular, showing a rather unusual range of functions from 'underneath' in one construction to 'on top of' in another. Thus different linguistic expressions of motion, location and direction interact in complex ways in Äiwoo in order to encode spatial relations.

\section{Discussion}

I suggest, then, that the unusual patterns in the use of directional verbs to encode stative spatial relations in Äiwoo can be understood as resulting from two competing cognitive-linguistic biases. Firstly, the bias towards dynamism (Talmy 2000), which is behind the fictive-motion construction discussed in 3.1-3.3, where stative spatial relations are construed as involving motion of the Figure towards the Ground. Secondly, the goal bias (Lakusta and Landau 2005; Regier and Zheng 2007), by which the resultant configuration of Figure and Ground is more salient than the motion that produces it, leading to the directional ee 'up' being used to encode configuration rather than motion in cases where the former is specified.

The ways in which directionals are used to encode stative spatial relations in Äiwoo shows how languages can exploit these cognitive-linguistic biases in complex ways. It is also an example of a phenomenon to which little attention has been paid in the literature on spatial language, namely the use of verbal, as opposed to adpositional/nominal, expressions to encode stative spatial relations. The contrast between the encoding of motion paths in the verb and in some expression outside the verb is very well-established, as it is the basis for Talmy's (1985, 1991) much-cited typology of "verb-framed" and "satelliteframed" languages; but much less attention has been paid to similar contrasts in the encoding of stative relations, presumably because encoding such relations in the verb is much less common. While a number of studies have looked at the 
uses of posture verbs in the encoding of stative spatial relations, these pertain largely to the shape and orientation of the Figure object (e.g. Newman 2002), or to the number and semantics of verbs employed in the "Basic Locative Construction" (Ameka and Levinson 2007) rather than the nature of the relation between the Figure and the Ground; whether an object is said to stand, sit, or lie on the table, for example, the relation between the object and the table is still largely the same. A well-described exception is Tzeltal, whose large system of "dispositional" verbs includes verbal forms with meanings such as 'be inserted in’ or 'be mounted on' (Brown 1994, 2006). Äiwoo, however, encodes such stative relations not by lexical verb roots but by a combination of different directional morphemes within the verb complex; a productive grammatical construction rather than a set of lexical distinctions.

As noted in 2.3, the linguistic encoding of stative spatial relations has frequently been described in terms of the concept of search domains: expressions such as above $X$ or in front of $X$ project a spatial region from a part of the Ground object $X$ and instruct the hearer to search for the Figure within this region. The Äiwoo data points to an alternative way in which languages can organise such relations: rather than using the Ground object to project a search domain, the hearer is instructed to trace a path from the Figure to the Ground (cf. Matlock 2004). That is, the construction casts the Ground object as a goal of motion and relates the Figure to it through a mental path towards the Ground from a particular direction, specified by the directionals. Of course, whether Äiwoo speakers actually locate objects in this way would need to be verified by independent experimentation; however, the construction does not naturally lend itself to interpretation in terms of a search domain. As defined by Hawkins (1981), this involves the specification of a particular region of the Ground object, but the spatial morphemes which specify the relation in Äiwoo refer to the Figure and its motion in a particular direction rather than to properties of the Ground.

Reference to a search domain is typically achieved by means of an adposition or a relational noun. By contrast, encoding of spatial relations within the verb might lend itself more naturally to construal in terms of fictive motion. Fictive motion can certainly be encoded by means of adpositions; Talmy's (2000) “Access Path" construction, as in The bakery is across the street from the bank, is an example of a construction in English which in a similar way locates the Figure "in terms of a path that some other entity might follow to the point of an encounter with the object" (Talmy 2000: 136). However, both the type of path encoded in the Äiwoo stative-location construction and the systematic way in which it is exploited in descriptions of stative spatial relations seems unusual, and may be linked to the formal means by which it is encoded, i.e. the use of directional 
markers on the verb. Whether this extensive use of fictive-motion constructions carries over to other languages where stative spatial relations are primarily encoded within the verb is a question for future research.

Another interesting direction for future research concerns the types of fictivemotion constructions found in languages with different systems for encoding spatial configurations. As noted in 3.3, I am only aware of one other language, Caac, for which a type of fictive path similar to that found in the Äiwoo stative relation construction has been described. However, most discussions of such constructions in the literature refer to languages with a significant range of different spatial prepositions. In Äiwoo, the single spatial preposition places significant constraints on what type of fictive paths can be felicitously represented. As seen in (3), the equivalent of The blood flowed from his eye to the bowl cannot be encoded in a single clause, because the source and goal arguments must be expressed in two distinct clauses; accordingly, fictive-motion constructions such as The fence goes from the plateau to the valley (Talmy 2000: 138) are not possible either. As noted in 2.3, the inability to encode source and goal in a single clause is common in languages which do not have distinct source and goal adpositions (Bohnemeyer et al. 2007). Accordingly, one cannot expect to find precisely the same kinds of fictive-motion constructions in languages which have only a single spatial preposition as in languages with a wide range of such prepositions, and a study of which types of fictive paths are encoded linguistically in languages having a single spatial preposition, and how these differ from those found with languages with multiple spatial prepositions, might yield interesting insights.

While this cannot be undertaken within the scope of the present paper, some preliminary data from Äiwoo can be offered. Äiwoo does not appear to use fictive-motion constructions for the kinds of cases where it is typically described for English, namely to describe the extension of an elongated object in space, as in The road runs from the mountain to the coast. While I have not tested this systematically with native speakers, the available examples in my data use $k o$ 'lie' in such cases:

(27) a. Nyäle ito, kâlâ kiekooli doowâ.

nyäle i-to, kâlâ ki-e-ko-oli doo=wâ

colour PFV-be there IPFV-PREF-lie-down like.that=DIST

'It has a colour, it goes [lit. lies] down like that.' (describes the appearance of stretch marks on a pregnant woman's body.)

b. Nubatage ikee Lipe ke.

nubatage i-ko-ee Lipe=ke

road PFV-lie-up place.name=PROX

'The road goes [lit. lies] up to Lipe.' 
By comparison, where only a direction is implied, fictive-motion constructions corresponding to a variety of Talmy's (2000) path types are possible, as with eâmole 'look' (28a), päi 'face' (28b), or täve 'hang' (28c):

(28) a. Iso ngâ nuwopa kâ mo le kiamoloolikä ngä nelo kâ.

i-so ngâ nuwopa=kâ mo le ki-eâmole-oli-kä
1MIN-stand LOC house=DIST CONJ PROX IPFV-look-down-DIR:3
ngä nelo=kâ
LOC sea=DIST
'I stood in the house and looked down to the sea.'
bäli kipäilâ Temââ ke
bäli ki-päi-lâ Temââ=ke
side IPFV-face-out Taumako=PROX
'the side that faces out towards Taumako island'
Mo nuwale eä nâ kitävooli.
mo nuwale eä=nâ ki-täve-oli
CONJ rope of.3MIN=DIST IPFV-hang-down
'And its [the kite's] string hangs down.'

Comparing Äiwoo to English, then, it appears that Äiwoo, with its single spatial preposition, both excludes certain fictive paths found in English ('the road runs from X to Y') and permits certain paths not found in English ('stand up to' = 'stand underneath'). A more systematic study of fictive paths encoded in languages with a single spatial adposition, or a very small inventory of spatial adpositions, might reveal to what extent these differences are indeed a function of the available inventory of morphemes expressing spatial relations in a language.

Acknowledgements: The author would like to thank the participants at the 9th Austronesian and Papuan Languages and Linguistics conference and three anonymous reviewers for helpful comments on earlier versions. Moreover, I gratefully acknowledge the support of the Endangered Languages Documentation Programme through a Small Grant (grant no. SG0308) which funded the collection and analysis of part of the data on which this work builds. Earlier fieldwork was funded by the Norwegian Research Council, project no. 148717.

\section{Abbreviations}

$\begin{array}{ll}\text { A } & \text { actor voice } \\ \text { ART } & \text { article } \\ \text { ATTR } & \text { attributive }\end{array}$




$\begin{array}{ll}\text { AUG } & \text { augmented number } \\ \text { BN } & \text { bound noun } \\ \text { CENTRIP } & \text { centripetal } \\ \text { COM.ART } & \text { common article } \\ \text { COM.LOC } & \text { common locative proclitic } \\ \text { CONJ } & \text { conjunction } \\ \text { CS } & \text { change of state } \\ \text { CV } & \text { circumstantial voice } \\ \text { DEF } & \text { default aspect } \\ \text { DEM } & \text { demonstrative } \\ \text { DIR } & \text { directional } \\ \text { DIST } & \text { distal } \\ \text { EVIT } & \text { evitative mood } \\ \text { FUT } & \text { future } \\ \text { IPFV } & \text { imperfective } \\ \text { IRR } & \text { irrealis } \\ \text { LD } & \text { locative-directional } \\ \text { LOC } & \text { locative } \\ \text { MIN } & \text { minimal number } \\ \text { NMLZ } & \text { nominaliser } \\ \text { O } & \text { undergoer voice } \\ \text { PFV } & \text { perfective } \\ \text { POSS } & \text { possessive } \\ \text { PREF } & \text { prefix (function unclear) } \\ \text { PRES } & \text { presentative } \\ \text { PRO:PP } & \text { pro-form for prepositional phrase } \\ \text { PROH } & \text { prohibitive } \\ \text { PROX } & \text { proximal } \\ \text { UA } & \text { unit-augmented number } \\ & \end{array}$

\section{References}

Ameka, Felix, Carlien de Witte \& David Wilkins. 1999. Picture series for positional verbs: Eliciting the verbal component in locative descriptions. In David Wilkins (ed.), Manual for the 1999 field season, 48-54. Nijmegen: Max Planck Institute for Psycholinguistics.

Ameka, Felix \& Stephen C. Levinson. 2007. The typology and semantics of locative predicates. [Special issue]. Linguistics 45(5-6). 847-871.

Báez, Gabriela Pérez \& Jürgen Bohnemeyer. 2008. Object to path in Mesoamerica: Semantic composition of locative and motion descriptions in Yucatec Maya and Juchitán Zapotec. In Rosa María Ortiz Ciscomani (ed.), Memorias del IX Encuentro Internacional de Lingüística en el Noroeste, Vol. 2. 269-284. Hermosillo, Sonora: Editorial UniSon.

Bohnemeyer, Jürgen, Nicholas J. Enfield, James Essegbey, Iraide Ibarretxe-Antuñano, Sotaro Kita, Friederike Lüpke \& Felix K. Ameka. 2007. Principles of event segmentation in language: The case of motion events. Language 83(3). 495-532. 
Bowerman, Melissa, Marianne Gullberg, Asifa Majid \& Bhuvana Narasimhan. 2004. Put project: The cross-linguistic encoding of placement events. In Asifa Majid (ed.), Field manual, vol. 9. 10-24. Nijmegen: Max Planck Institute for Psycholinguistics.

Bowerman, Melissa \& Asifa Majid. 2003. Kids' cut \& break. In Nicholas J. Enfield (ed.), Field research manual 2003, part I: Multimodal interaction, space, event representation, 70-71. Nijmegen: Max Planck Institute for Psycholinguistics.

Brown, Penelope. 1994. The INs and ONs of Tzeltal locative expressions: The semantics of static descriptions of locations. Linguistics 32(4-5). 743-790.

Brown, Penelope. 2006. A sketch of the grammar of space in Tzeltal. In Stephen C. Levinson \& David Wilkins (eds.), Grammars of space: Explorations in cognitive diversity, 230-272. Cambridge: Cambridge University Press.

Cablitz, Gabriele H. 2006. Marquesan: A grammar of space. Berlin: Mouton de Gruyter.

Cauchard, Aurélie. 2014. A study of space in Caac, an Oceanic language spoken in the north of New Caledonia. Manchester, UK: University of Manchester dissertation.

Cauchard, Aurélie. ms. Seawards towards us ... and back. Fuzzy boundaries between factive and fictive motion in a New Caledonian language. Unpublished manuscript.

Foley, William A. \& Mike Olson. 1985. Clausehood and verb serialization. In Johanna Nichols \& Anthony C. Woodbury (eds.), Grammar inside and outside the clause: Some approaches to theory from the field, 17-60. Cambridge: Cambridge University Press.

François, Alexandre. 2004. Reconstructing the geocentric system of Proto-Oceanic. Oceanic Linguistics 43(1). 1-31.

Freeman, N. H., C. G. Sinha \& J. A. Stedmon. 1980. The allative bias in 3-year-olds is almost proof against task naturalness. Journal of Child Language 8(2). 283-296.

Frostad, Benedicte H. 2012. A grammar of Ughele. Nijmegen: Radboud University dissertation. Hammarström, Harald, Sebastian Bank, Robert Forkel \& Martin Haspelmath. Glottolog 3.2. http://glottolog.org/ (accessed 14 February 2018).

Hawkins, Bruce W. 1981. Variable temporal integration between motional verbs and locational prepositions. Linguistic Notes from La Jolla 10. 98-127.

Hellwig, Birgit \& Friederike Lüpke. 2001. Caused positions. In Stephen C. Levinson \& Nicholas J. Enfield (eds.), Manual for the field season 2001, 126-128. Nijmegen: Max Planck Institute for Psycholinguistics.

Lakusta, Laura \& Barbara Landau. 2005. Starting at the end: The importance of goals in spatial language. Cognition 96(1). 1-33.

Langacker, Ronald W. 1987. Foundations of cognitive grammar. Vol. I: Theoretical prerequisites. Stanford: Stanford University Press.

Levinson, Stephen C. 2003. Space in language and cognition: Explorations in cognitive diversity. Cambridge: Cambridge University Press.

Lynch, John, Malcolm Ross \& Terry Crowley. 2002. The Oceanic languages. Richmond: Curzon. Malau, Catriona. 2016. A grammar of Vurës, Vanuatu. Boston: de Gruyter Mouton.

Matlock, Teenie. 2004. The conceptual motivation of fictive motion. In Günter Radden \& KlausUwe Panther (eds.), Studies in linguistic motivation, 221-248. Berlin: Mouton de Gruyter.

Mosel, Ulrike \& Even Hovdhaugen. 1992. Samoan reference grammar. Oslo: Scandinavian University Press.

Næss, Åshild. 2015. Voice at the crossroads: Symmetrical clause alternations in Äiwoo, Reef Islands, Solomon Islands. Oceanic Linguistics 54(1). 270-307.

Næss, Åshild. 2017. A short dictionary of Äiwoo. Canberra: Asia-Pacific Linguistics. https:// openresearch-repository.anu.edu.au/handle/1885/112469 (accessed 27 August 2018). 
Næss, Åshild \& Mathias Jenny. 2011. Who changes language? Bilingualism and structural change in Burma and the Reef Islands. Journal of Language Contact 4. 217-249.

Newman, John (ed.). 2002. The linguistics of sitting, standing and lying. Amsterdam: John Benjamins.

Regier, Terry \& Mingyu Zheng. 2007. Attention to endpoints: A cross-linguistic constraint on spatial meaning. Cognitive Science 31(4). 705-719.

Ross, Malcolm \& Åshild Næss. 2007. An Oceanic origin for Äiwoo, the language of the Reef Islands? Oceanic Linguistics 46(2). 456-498.

Staden, Miriam van, Gunter Senft, Nicholas J. Enfield \& Jürgen Bohnemeyer. 2001. Staged events. In Stephen C. Levinson \& Nicholas. J. Enfield (eds.), Manual for the field season 2001, 115-125. Nijmegen: Max Planck Institute for Psycholinguistics.

Talmy, Leonard. 1983. How language structures space. In Herbert L. J. Pick \& Linda P. Acredolo (eds.), Spatial orientation: Theory, research, and application, 225-282. New York: Plenum Press.

Talmy, Leonard. 1985. Lexicalization patterns: Semantic structure in lexical forms. In Timothy Shopen (ed.), Language typology and syntactic description. Vol. III: Grammatical categories and the lexicon, 57-149. Cambridge: Cambridge University Press.

Talmy, Leonard. 1991. Path to realization: A typology of event conflation. In Proceedings of the Seventeenth Annual Meeting of the Berkeley Linguistics Society: General session and parasession on the grammar of event structure, 480-519.

Talmy, Leonard. 2000. Toward a cognitive semantics. Vol. I: Concept structuring systems. Cambrige, MA: MIT Press.

Thiering, Martin. 2011. Figure-ground reversals in language. Gestalt Theory 33(3/4). 245-276. 